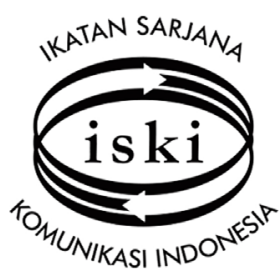

\title{
PERILAKU KOMUNIKASI POLITIK PEMILIH PEMULA DI PILKADA KABUPATEN BANDUNG
}

\author{
Aat Ruchiat Nugraha ${ }^{1}$, Nuryah Asri Sjarifah ${ }^{2}$, Heru Ryanto Budiana $^{3}$ \\ ${ }^{1,2,3}$ Fakultas Ilmu Komunikasi Universitas Padjajaran \\ Jl. Hegarmanah, Jatinangor, Sumedang \\ ruchiat@unpad.ac.id,heru.prodihumas@gmail.com
}

\begin{abstract}
Abstrak
Perebutan kekuasaan melalui kegiatan pemilihan umum menjadi hal yang baru dalam sistem ketatanegaraan Indonesia dengan diterapkannya sistem pemilihan langsung secara serentak di daerah. Pemilihan langsung di daerah memberikan peluang strategis bagi masyarakat sebagai penentu dalam mengarahkan pembangunan daerahnya di masa depan. Masyarakat memiliki daya tawar yang tinggi bagi seorang kandidat yang bertarung di Pilkada, sehingga perilaku masyarakat berpolitik dalam Pilkada menjadi sangat penting untuk diperhatikan. Pemilih pemula yang merupakan bagian dari masyarakat, memiliki perilaku komunikasi politik tersendiri dalam menentukan pilihannya. Metode pendekatan penelitian yang digunakan adalah kuantitatif dengan jenis data deskriptif. Hasil penelitian menunjukkan, sebagian besar pemilih pemula sangat terbuka terhadap perubahan secara kultural, pendidikan, maupun teknologi yang disampaikan melalui media massa dan komunikasi antarpesona sehingga memunculkan karakteristik pemilih pemula yang memilih pemimpin berdasarkan pertimbangan rasional, psikologis, dan sosiologis.
\end{abstract}

Kata Kunci: Pilkada, Perilaku Komunikasi Politik, Pemilih Pemula, Pemilihan Langsung.

\section{PENDAHULUAN}

Perkembangan politik dan demokrasi sekarang ini identik dengan bisnis-komersial. Kondisi seperti ini secara praktis dalam dinamika politik membutuhkan partisipasi dari berbagai stakeholders guna menunjang perolehan kekuasaan. Pemilihan Umum yang baik dan bersih, mensyaratkan adanya pemilih yang mempunyai pengetahuan, kesadaran dan bebas dari intimidasi berbagai pihak. Dalam rangka itulah, proses pemilu baik legislatif, presiden dan wakil presiden maupun pemilu kepala daerah dan wakil kepala daerah perlu ditanggapi secara kritis oleh masyarakat, khususnya pemilih.

Masyarakat (rakyat) sebagai alat utama yang menentukan seseorang dapat berkuasa di sistem ketatanegaraan yang langsung seperti sekarang ini menjadi sangat penting untuk diperhatikan oleh pemerintah. Adanya masyarakat maka sistem pemerintahan dan ketatanegaraan dapat berjalan baik di pusat maupun di daerah. Untuk sistem pemerintahan di daerah, pemerintah telah memberikan peluang kepada seluruh masyarakat yang berdomisili di daerah tersebut untuk dapat berpartisipasi menjadi bagian dalam kegiatan penyelenggaraan mekanisme pemerintahan daerah secara demokratis, yaitu melalui kegiatan pemilihan kepala daerah (Pilkada).

Pada sistem politik demokrasi yang telah disebutkan sebelumnya, maka kehadiran pemilu yang bebas dan adil adalah suatu harapan. Sehingga perilaku politik seseorang itu bisa berbeda-beda. Ikut serta dan bergabungnya seseorang dalam partai politik juga merupakan bentuk dari perilaku politik. Hal ini dikarenakan bahwa partai politik merupakan sarana bagi warga negara untuk turut berpartisipasi dalam proses pengelolaan negara dan menjalankan kebijakan-kebijakan untuk negara.

Penyelenggaraan pilkada di suatu daerah harus 
memperhatikan generasi muda. Sebab generasi muda yang terdiri atas remaja dan pemuda merupakan pemilih pemula yang belum memiliki kepentingan akan suatu kekuasaan di pemerintahan. Dengan demikian, keikutsertaan pemilih pemula menjadi hal yang utama dalam ajang Pilkada di daerah-daerah yang merupakan bagian dari proses yang melibatkan seluruh warga negara baik itu yang berasal dari kelompok mayoritas sampai kelompok minoritas dalam aktivitas politik yang dapat mengakibatkan perilaku dalam memilih tidak hanya dilakukan oleh pemilih lama.

Perilaku pemilih dalam pilkada itu sangat penting, dikarenakan apabila pelaksanaan pilkada berjalan sukses, maka tentu saja perilaku pemilih sukses juga. Pemilu telah menjadi keniscayaan yang tidak dapat dielakkan dalam era demokrasi ini, untuk itu perlu kiranya pengenalan lebih dini terhadap arti, makna, dan fungsi pemilu/Pilkada bagi para calon pemilih.

Pemilih pemula adalah pemilih yang baru pertama kali akan melakukan penggunaan hak pilihnya. Pemilih pemula terdiri dari masyarakat yang telah memenuhi syarat untuk memilih. Adapun syarat-syarat yang harus dimiliki untuk menjadikan seseorang dapat memilih adalah: (1) umur sudah 17 tahun; (2) sudah/pernah kawin dan; (3) purnawirawan/sudah tidak lagi menjadi anggota TNI/Polri.

Pengenalan proses pemilu sangat penting untuk dilakukan kepada pemilih pemula terutama mereka yang berusia 17 tahun. Pemerintah dibantu dengan pihak terkait lainnya harus mampu memberikan kesan awal yang baik tentang pentingnya suara pemilih pemula dalam pemilu, bahwa suara mereka dapat menentukan pemerintahan selanjutnya dan meningkatkan kesejahteraan hidup bangsa. Pemahaman yang baik itu diharapkan dapat menjadi motivasi untuk terus menjadi pemilih yang cerdas. Secara umum, pemuda (pelajar) sebagaimana masyarakat umum selalu menjadi objek politik. Mereka hanya dilirik untuk hitungan suara saja, tidak lebih. Hal ini tentu mengakibatkan tidak tercapainya tujuan pendidikan politik itu sendiri selama ini, yakni pencerdasan politik.

Dalam hal ini peneliti yang mencoba meneliti perilaku pemilih di salah satu rayon SMA yang berada di kecamatan yang ada di Kabupaten Bandung tidak berdasarkan etnis, agama dan geografis, namun mencoba menganalisa dari kasus yang kecil yakni berupa perilaku siswa dalam partisipasi politik yang sering disebut-sebut sebagai kelompok yang paling pemula dalam melaksanakan aktivitas politik atau hak politiknya. Dalam kelompok-kelompok sosial tersebut terdapat seperangkat norma, nilai dan gagasan yang berlaku dan tersosialisasikan melalui proses yang panjang. Hal inilah yang nantinya berpengaruh terhadap preferensi dan perilaku politik.

Berdasarkan observasi lapangan, karakteristik pemilih pemula pada generasi milenia atau generasi Y (angkatan 1980-1990) di wilayah Kabupaten Bandung cukup bervariasi yang ditandai dengan pola pikir yang sangat terbuka terhadap ide gagasan yang disampaikan melalui media tertentu ataupun generasi $\mathrm{Y}$ tersebut aktif dalam berorganisasi yang menyebabkan mereka kreatif dan tidak konservatif terhadap dogma-dogma politik, budaya, dan agama yang disampaikan oleh teknologi komunikasi yang semakin canggih. Di sisi lain, ciri yang mempengaruhi pemilih pemula sehingga sangat penting untuk diperhatikan yaitu secara stabilitas emosional masih termasuk kategori labil. Kondisi labil secara emosi tersebut tentunya dapat dimanfaatkan oleh tim sukses pasangan kepala daerah untuk mempersuasi pemilih pemula agar berpartisipasi dengan harapan memberikan dukungan suara di saat pencoblosan dilakukan. Upaya persuasi yang sesuai dengan karakteristik pemilih pemula di wilayah kabupaten Bandung secara pendekatan komunikasi harus dilakukan melalui penyampaian informasiinformasi atau pesan politik yang dikemas dengan menggunakan bahasa-bahasa anak remaja yang elegan, kreatif, komunikatif, dan syarat dengan nilainilai emosional.

Fenomena pemilih pemula menunjukkan bahwa pemilih ini semakin diperhatikan karena memiliki daya magnet tertentu bagi aktor politik. Mereka tidak dengan mudah mengikatkan diri dengan suatu idiologi kepartaian yang ditawarkan, tetapi lebih tertarik pada tawaran-tawaran yang mendukung terhaap life style pemilih pemula. Potensi pemilih pemula ini bisa membuat menjadi potensi massa yang sifatnya mengambang, dalam artian seringkali sangat menentukan menang-tidaknya suatu kandidat dalam pertarungan perebutan kekuasaan melalui peraihan suara yang didualng oleh suatu partai atau kandidat tertentu. Massa mengambang menurut Firmanzah (2008:38) adalah kelompok masyarakat yang akan diperebutkan oleh partai-partai yang bersaing dalam pemilihan umum. Kemunculan massa mengambang 
ini semakin besar seiring dengan semakin kritisnya masyarakat terhadap hasil kinerja keberadaan di lembaga eksekutif, lembaga legislatif, maupun di lembaga yudikatif.

Pada dasarnya perilaku politik sangat bergantung kepada budaya politik yang membentuk perilaku keteraturan. Selain itu, perilaku politik didukung oleh situasi politik yang dimana mencakup berbbagai masalah, tanggapan-tanggapan emosional, berupa dukungan maupun apati kepada pemerintah, tanggapan terhadap peundangan dan kebijaksanaankebijaksanaan yang berkaitan dengan masyarakat. Dengan demikian, perilaku politik menurut Rusadi dalam Harun dan Sumarno (2006:102) akan tumbuh dan berkembang atas dasar kesadaran dari hasil pemahaman dan pendalaman terhadap sistem yang sedang berlangsung.

Berangkat dari fakta dan realitas yang diuraikan diatas, bahwa perilaku pemilih pemula pada kalangan SMA di Kabupaten Bandung memiliki karakteristik tertentu untuk dijadikan sasaran objek laboratorium politik. Dengan kata lain, dari fenomena tersebut diangkat oleh peneliti dengan tujuan untuk mengetahui dan memahami tentang faktor-faktor apa saja yang melatarbelakangi pemilih pemula menyuarakan pilihannya atau ikut berpartisipasi dalam pemilihan umum kepala daerah (Pilkada) di Kabupaten Bandung.

\section{KERANGKA TEORITIS}

Secara umum pendekatan perilaku pemilih dalam ilmu politik terbagi ke dalam tiga garis besar pendekatan/model (Harrop dan Miller, 1987: 130-161). Pertama, pendekatan yang sangat psikologis yang disebut identifikasi partai (party identification). Kedua, pendekatan yang menganggap individu memiliki kapasitas rasional untuk menentukan pilihan-pilihannya (rational choice). Pemilih dianggap memahami, mengapa ia memilih, apa dampak dari pilihannya itu dan ia sadar betul pilihan yang diambil adalah instrumen penting bagi artikulasi kepentingan politiknya. Pendekatan yang terakhir, adalah pendekatan secara sosiologis (sociological approach). Pendekatan ini melihat pentingnya basis sosial dalam menentukan perilaku memilih. Misalkan, identitas sosial seperti agama, kelas sosial, dan suku bangsa menjadi alasan utama seseorang memilih sebuah partai atau seorang kandidat.

Pendekatan party identification menekankan pentingnya keluarga dalam sosialisasi politik terhadap anak, hingga mentransmisikan apa yang disebut dengan psychological attachment (kedekatan psikologis) antar generasi. Nilai-nilai kesetiaan terhadap partai atau figur tertentu ditransmisikan kepada anak pada saat usianya masih sangat belia (antara 10-11 tahun). Pengaruh keluarga ini terus berlangsung hingga anak dewasa meskipun berjalan sangat cair dengan lingkungannya sepanjang masa. Hingga akhirnya, sang anak memahami politik sebagaimana orang tua mereka. Masa anak-anak hingga remaja dan dewasa inilah yang diklaim pendekatan ini menentukan perilaku memilih dan pilihan politik seseorang.

Sementara itu, pendekatan rational choices menganggap pemilih merupakan individu bebas. Individu memilih bukan karena adanya kedekatan psikologis dengan calon atau partai tertentu. Seseorang menentukan pilihan politiknya tidak berdasarkan latar belakang keluarga, budaya maupun kelas sosial di mana dia berada. Pilihan-pilihan politik tersebut murni sebagai pencerminan kepentingan pribadinya. Seluruh pemilih dalam pendekatan ini dianggap memahami benar makna pilihannya dan dampaknya bagi dirinya. Masalahnya, pendekatan ini hanya mampu memahami individu dengan ukuran-ukuran tertentu. Misalnya, si pemilih harus berpendidikan tinggi, tingat ekonomi yang mumpuni dan sebagainya. Prasarat ini sepertinya yang harus dipenuhi terlebih dulu, jika ingin menganggap individu menjadi rasional dalam memilih.

Pendekatan terakhir yaitu pendekatan sosiologis, yang di mana melihat pentingnya basis sosial seseorang di masyarakat. Basis sosial diartikan cukup beragam, misalnya agama, kepercayaan, suku, dan kelas sosial yang dimiliki seseorang. Apabila sebagai pemilih, maka pendekatan ini akan memulai analisanya dari faktor-faktor agama, kepercayaan, suku, dan kelas sosial. Sebagai contohnya, kalau pemilih beragama Islam, maka ada kemungkinan besar pemilih akan memilih partai Islam.

Karakteristik pemilih dalam politik didukung dari hasil kajian lainnya, yaitu dari Clifford Geertz dalambukuberjudul The Religion ofJava (1961) dengan sub judulnya Java Voters yang telah diterjemahkan oleh Mahasim (1981) yang telah menjadi rujukan klasik. Hasil penelitiannya menunjukkan bahwa karakter pemilih di Jawa menjadi terbagi menjadi tiga, antara lain santri, abangan, dan priyayi. Namun, kategorisasi yang agak aneh tersebut banyak dikritik, khususnya kategori priyayi yang merupakan kelas 
sosial. Berbeda dengan santri dan abangan yang menjelaskan kategori tingkat ketaatan religi dalam Islam.

Sebagai bandingan karakteristik pemilih di Indonesia dengan negara lain, khususnya di Australia dapat dilihat dari hasil kajian Ian Mc Allister (1992) dalam bukunya, Political Behaviour: Citizen, Parties, and Elites in Australia, mencatat perilaku pemilih Australia terfokus pada (1) faktor struktural, yaitu memilih berdasarkan kedekatan kelas sosialekonomi, desa-kota, dan lain sebagainya, dan (2) faktor ekologi, yaitu memilih berdasarkan pada kedekatan karakterisik wilayah seperti daerah pedalaman, pesisir, pertanian, perkebunan, dan sebagainya.

Jadi, dalam perspektif yang lebih kompleks dan holistik setidaknya ada lima faktor yang memengaruhi perilaku pemilih, yakni faktor sosiologi (etnis, aliran), psikologi, rasional-pragmatis, struktural, dan ekologi. Faktor-faktor ini bersifat komplementatif, relatif, dan tentu saja tidak absolut.

Perilaku pemilih tidak sama dengan sifat pemilih. Harun dan Sumarno (2006:101) menyatakan bahwa perilaku politik merupakan cerminan dari budaya politk suatu masyarakat. Atau sebagai cerminan dari suatu pola keyakinan tertentu yang menjadi identitas pembeda terhadap perilaku menurut pola-pola lain. Hal senada yang dikemukakan oleh Surbakti bahwa perilaku politik merupakan suatu kegiatan ataupun aktivitas yang berkenaan ataupun berhubungan langsung dengan proses politik, baik itu dalam pembuatan keputusan politik sampai kepada pelaksanaan aktivitas politik secara periodik. Di dalam pelaksanaan pemilihan umum suatu negara, baik pemilu tingkat daerah maupun tingkat pusat perilaku politik berupa perilaku pemilih dalam menentukan sikap dan pilihan dalam melaksanakan pemilihan umum atau pemilukada tersebut. Pemilih diartikan sebagai pihak atau individu yang menjadi tujuan utama para kontestan untuk mempengaruhi mereka dan meyakinkan mereka agar mendukung dan memilih kontestan politik yang bersangkutan. Pemilih dalam hal ini merupakan konstituen maupun masyarakat pada umumnya.

\section{METODE PENELITIAN}

\section{Populasi dan Sampel}

Berdasarkan tujuan yang ditetapkan untuk mengetahui latar belakang pemilih beserta kecenderungan perilaku pemilih pemula, maka jenis penelitian ini menggunakan pendekatan kuantitatif deskriptif, yang akan menjelaskan faktor-faktor yang berhubungan dengan pilihan pemilih pemula dalam pilkada serentak. Berdasarkan data BPS kabupaten Bandung menurut pencatatan akhir 2012 di Kabupaten Bandung memiliki penduduk sejumlah 3.351.048 jiwa. Populasi dalam survei ini meliputi para siswa SMA Negeri di Kabupaten Bandung yang memiliki hak pilih. Mengacu pada rayon sebaran jumlah SMA di Kabupaten Bandung yang merujuk pada jumlah kecamatan yaitu ada 31 kecamatan. Adapun metode sampling yang digunakan adalah stratified random sampling. Karena unsur populasi berkarakteristik homogenitas (unsur kewilayahan dan status pendidikan yang sama), dan homogenitas tersebut mempunyai arti yang signifikan pada pencapaian tujuan penelitian yang akan diteliti.

Berdasarkan data dari dinas pendidikan dasar dan menengah Kabupaten Bandung pada tahun ajaran 2013/2014 menunjukkan bahwa daya tampung SMA/SMK terbagi menjadi tiga wilayah yaitu Wilayah I meliputi Kecamatan Cangkuang, Ciwidey, Katapang, Kutawaringin, Margaasih, Margahayu, Pasirjambu, Rancabali dan Soreang. Wilayah II meliputi Kecamatan Arjasari, Baleendah, Banjaran, Cimaung, Ciparay, Dayeuhkolot, Kertasari, Pacet, Pameungpeuk, dan Pangalengan. Wilayah III meliputi Kecamatan Cicalengka, Cikancung, Cilengkrang, Cileunyi, Cimenyan, Ibun, Majalaya, Nagreg, Paseh, Rancaekek dan Selokan Jeruk.

Merujuk pada objek penelitian yaitu pelajar SMA Negeri yang ada di wilayah Kabupaten Bandung, maka berdasarkan teknik sampling acak sederhana terpilih tiga SMAN yang ada di Dayeuhkolot, Baleendah, dan Cileunyi dengan jumlah pelajar kelas XI sebanyak 1.081 orang.

Dengan menggunakan rumus Yamane (1967: 99, dalam Rakhmat):

$$
n=\frac{N}{N \cdot d^{2}+1}
$$

\section{Keterangan:}

$\mathrm{n}=$ ukuran sampel

$\mathrm{N}=$ ukuran populasi

$\mathrm{d}=$ tingkat kepercayaan/ketepatan yang diinginkan, pressisi $5 \%$

maka didapat jumlah sampel 268 orang siswa SMA kelas XI di Kabupaten Bandung. 


\section{Metode Pengumpulan Data}

Dalam penelitian ini pengumpulan data dilakukan dengan cara penyebaran angket sebagai data primer. Dimana penyebaran angket ini dilakukan dengan cara membagikan kepada responden sebanyak 268 orang siswa kelas XI yang ada di wilayah Kabupaten Bandung yang terindikasi dan berpotensi sebagai pemilih pemula di masa yang akan datang apabila pemilihan umum dilakukan.

\section{Teknis Analisis Data}

Pada penelitian ini, teknik analisis data yang digunakan adalah analisis statistik deskriptif yang didahului dengan uji validitas dan reliabilitas dengan menggunakan program SPSS 16. Menurut Arikunto (1995) dalam Riduwan (2004:97) menjelaskan bahwa yang dimaksud dengan validitas adalah suatu ukuran yang menunjukkan tingkat keandalan atau kesahihan suatu alat ukur. Hal senada juga dinyatakan oleh Singarimbun (1989:124) bahwa validitas menunjukkan sejauhmana suatu alat pengukur itu mengukur apa yang ingin diukur. Tingkat validitas angket diukur berdasarkan koefisien validitas yang dalam hal ini menggunakan korelasi item total yang terkoreksi. Suatu pertanyaan dikatakan valid dan dapat mengukur varibel penelitian yang dimaksud jika nilai koefisien validitasnya lebih dari atau sama dengan 0,300 (Kaplan dan Saccuzo,1993). Penelitian ini menggunakan pengujian validitas konstruk yang dilakukan melalui pengujian validitas setiap butir pertanyaan. Dari hasil perhitungan menunjukkan bahwa butir pertanyaan dapat dinyatakan valid bila dibandingkan dengan nilai $r$ tabel, dari hasil perhitungan diperoleh nilai $r$ tabel (df:2, $\alpha: 0,05)$ sebesar 0,232 , yang dapat dilihat dibawah ini:

Tabel 1

Uji Validitas Variabel

\begin{tabular}{|c|c|c|c|}
\hline $\begin{array}{c}\text { Butir } \\
\text { Pertanyaan }\end{array}$ & r Korelasi & r Tabel & Kesimpulan \\
\hline 1 & 0,493 & 0,232 & Valid \\
\hline 2 & 0,377 & 0,232 & Valid \\
\hline 3 & 0,645 & 0,232 & Valid \\
\hline 4 & 0,548 & 0,232 & Valid \\
\hline 5 & 0,327 & 0,232 & Valid \\
\hline 6 & 0,343 & 0,232 & Valid \\
\hline 7 & 0,557 & 0,232 & Valid \\
\hline 8 & 0,378 & 0,232 & Valid \\
\hline
\end{tabular}

\begin{tabular}{|c|c|c|c|}
\hline $\begin{array}{c}\text { Butir } \\
\text { Pertanyaan }\end{array}$ & r Korelasi & r Tabel & Kesimpulan \\
\hline 9 & 0,455 & 0,232 & Valid \\
\hline 10 & 0,308 & 0,232 & Valid \\
\hline 11 & 0,338 & 0,232 & Valid \\
\hline
\end{tabular}

Sumber: Angket, 2015

Reliabilitas menunjukkan sejauhmana tingkat kekonsistenan pengukuran dari suatu responden ke responden yang lain atau dengan kata lain sejauhmana pertanyaan dapat dipahami sehingga tidak menyebabkan beda interpretasi dalam pemahaman pertanyaan tersebut. Sekumpulan pertanyaan untuk mengukur suatu variabel dikatakan reliabel dan berhasil mengukur variabel yang diukur jika koefisien reliabilitasnya lebih dari atau sama dengan 0,700 (Kaplan dan Saccuzo, 1993). Metode yang digunakan dalam pengujian reliabilitas ini adalah menggunakan metode alpha cronbach, dengan hasil perhitungan menunjukkan sebagai berikut:

Tabel 2

Uji Reliabilitas Variabel

\begin{tabular}{|c|c|c|c|c|}
\hline $\begin{array}{c}\text { Butir Per- } \\
\text { tanyaan }\end{array}$ & Variansi & Alpha & r Tabel & $\begin{array}{c}\text { Kesim- } \\
\text { pulan }\end{array}$ \\
\hline 1 & 65.333 & 0.878 & 0.232 & Reliabel \\
\hline 2 & 67.943 & 0.880 & 0.232 & Reliabel \\
\hline 3 & 65.238 & 0.870 & 0.232 & Reliabel \\
\hline 4 & 69.385 & 0.874 & 0.232 & Reliabel \\
\hline 5 & 71.869 & 0.880 & 0.232 & Reliabel \\
\hline 6 & 71.169 & 0.879 & 0.232 & Reliabel \\
\hline 7 & 69.611 & 0.874 & 0.232 & Reliabel \\
\hline 8 & 71.848 & 0.879 & 0.232 & Reliabel \\
\hline 9 & 70.761 & 0.877 & 0.232 & Reliabel \\
\hline 10 & 71.733 & 0,880 & 0.232 & Reliabel \\
\hline 11 & 70.648 & 0.880 & 0.232 & Reliabel \\
\hline
\end{tabular}

Sumber: Angket, 2015

\section{HASIL PENELITIAN}

Pada tahun 2015, Pemerintah menggelar pemilihan kepala daerah secara serentak di 204 provinsi, kota, dan kabupaten. Adapun untuk wilayah provinsi Jawa Barat penyelenggaraan pemilu kepala daerah (Pilkada) serentak 2015 terdiri dari pemilihan umum di Kabupaten Pangandaran, Kabupaten Tasikmalaya, Kabupaten Karawang, Kabupaten Cianjur, Kabupaten Bandung, Kota Depok, 
Kabupaten Sukabumi, dan Kabupaten Indramayu.

Untuk mengetahui gambaran tentang kecenderungan kesiapan para calon pemilh pemula dalam keterlibatan di pilkada, khususnya yang diselenggarakan di Kabupaten Bandung dapat dijelaskan melalui sajian tabel distribusi frekuensi tentang kecenderungan perilaku komunikasi pelajar SMA negeri di Kabupaten Bandung dengan rinciannya sebagai berikut:

Tabel 3

Dalam pilihan Pilkada, Anda tidak mempertimbangkan latar belakang asal daerah (suku/etnis) tertentu kandidat

\begin{tabular}{|l|l|l|}
\hline Pernyataan & $\mathbf{f}$ & \% \\
\hline Sangat Setuju & 92 & 34,3 \\
\hline Setuju & 101 & 37,7 \\
\hline Netral & 18 & 6,7 \\
\hline Tidak Setuju & 42 & 15,7 \\
\hline Sangat Tidak Setuju & 15 & 5,6 \\
\hline Jumlah & $\mathbf{2 6 8}$ & $\mathbf{1 0 0}$ \\
\hline
\end{tabular}

Sumber: Angket, 2015

Berdasarkan pada tabel diatas, menunjukkan bahwa jawaban terhadap item tersebut, sebanyak 92 responden atau 34,3 persen memberikan jawaban sangat setuju, sebanyak 101 responden atau 37,7 persen menyatakan setuju, sebanyak 18 responden memberikan jawaban netral atau 6,7 persen, sebanyak 42 responden memberikan jawaban tidak setuju atau 15,7 persen, dan sebanyak 15 responden memberikan jawaban sangat tidak setuju atau 5,6 persen.

Isu kedaerahan (kesukuan) masih menjadi tolak ukur sebagian besar responden yaitu sebanyak 193 orang menyatakan bahwa responden akan memilih kandidat pasangan bupati dan wakil bupati yang berasal dari daerah asal (suku Sunda). Hal ini mereka ungkapkan karena pemimpin itu harus yang tahu akan kondisi wilayahnya, sehingga yang namanya pilkada adalah memilih pemimpin tingkat daerah maka seharusnya orang daerah lah yang memimpin (orang Sunda). Menurut Firmanzah (2008:123) pemilih pemula yang mempertunjukkan pilihannya terhadap fanatik kesukuan termasuk kategori pemilih tradisional. Pemilih tradisional sangat mengutamakan kedekatan sosial-budaya, nilai, asalusul, dan agama sebagai ukuran untuk memilih partai atau kontestan yang menjadi pilihannya.
Tabel 4

Dalam pilihan Pilkada, Anda mempertimbangkan latar belakang agama yang dianut oleh kandidat

\begin{tabular}{|l|c|c|}
\hline Pernyataan & f & $\%$ \\
\hline Sangat Setuju & 48 & 17,9 \\
\hline Setuju & 71 & 26,5 \\
\hline Netral & 91 & 33,9 \\
\hline Tidak Setuju & 50 & 18,7 \\
\hline Sangat Tidak Setuju & 8 & 3 \\
\hline Jumlah & $\mathbf{2 6 8}$ & $\mathbf{1 0 0}$ \\
\hline
\end{tabular}

Sumber: Angket, 2015

Berdasarkan pada tabel di atas, menunjukkan bahwa jawaban terhadap item tersebut, sebanyak 48 responden atau 17,9 persen memberikan jawaban sangat setuju, sebanyak 71 responden atau 26,5 persen menyatakan setuju, sebanyak 91 responden memberikan jawaban netral atau 33,9 persen, sebanyak 50 responden memberikan jawaban tidak setuju atau 18,7 persen, dan sebanyak 8 responden memberikan jawaban sangat tidak setuju atau 3 persen.

Kejelasan akan agama yang dianut oleh calon pasangan kandidat bupati dan wakil bupati Bandung, masih menjadi pertimbangan sebagian besar 118 responden atau 45 persen menyatakan sangat setuju dan setuju apabila dalam Pilkada nanti preferensi unsur agama menjadi isu yang sangat penting dan dijadikan patokan pemilih pemula. Apabila dikaitkan dengan hasil tabel dari identitas responden mengenai agama yang dianut menunjukkan bahwa para pelajar yang berlatarbelakang menganut agama Islam, masih bersikukuh untuk memilih calon pemimpin yang didasari oleh nilai-nilai agama, khususnya agama Islam. Pemilih pemula yang masih terikat atau menunjukkan tingkat keloyalan pada agama atau keyakinan yang dianutnya, masih termasuk kategori pemilih tradisional yang masih bisa dimobilisasi selama periode kampanye berlangsung (Rohscheneider, 2002) dalam Firmazah (2008:123).

Dalam terminologi komunikasi, agama merupakan konsep yang dapat mempengaruhi cara seseorang dalam berkomunikasi. Karena dalam ajaran agama terdapat pedoman tata cara untuk menyampaikan pesan-pesan yang baik dalam berhubungan dengan tuhan, manusia dan alam sekitar. Sehingga hubungannya dengan kegiatan pemilihan kepala daerah yang berlatar belakang agama yang 
baik, maka diharapkan akan dapat memimpin daerah secara amanah, jujur dan adil demi terwujudnya keadilan sosial bagi seluruh masyarakat Indonesia atau lebih maslahat.

Tabel 5

Dalam pilihan Pilkada, Anda tidak mempertimbangkan latar belakang partai politik yang dijadikan kendaraan politik oleh kandidat

\begin{tabular}{|l|l|l|}
\hline Pernyataan & f & \% \\
\hline Sangat Setuju & 26 & 9,7 \\
\hline Setuju & 90 & 33,6 \\
\hline Netral & 82 & 30,5 \\
\hline Tidak Setuju & 59 & 22 \\
\hline Sangat Tidak Setuju & 11 & 4,2 \\
\hline Jumlah & $\mathbf{2 6 8}$ & $\mathbf{1 0 0}$ \\
\hline
\end{tabular}

Sumber: Angket, 2015

Berdasarkan pada tabel diatas, menunjukkan bahwa jawaban terhadap item tersebut, sebanyak 26 responden atau 9,7 persen memberikan jawaban sangat setuju, sebanyak 90 responden atau 33,6 persen menyatakan setuju, sebanyak 82 responden memberikan jawaban netral atau 30,5 persen, sebanyak 59 responden memberikan jawaban tidak setuju atau 22 persen, dan sebanyak 11 responden memberikan jawaban sangat tidak setuju atau 4,2 persen.

Adanya pencalonan dari jalur perseorangan memberikan peluang bagi para pemilih pemula untuk dijadikan preferensi lain dalam pemilihan kepala daerah Bupati dan Wakil Bupati di kabupaten Bandung. Dari tabel diatas dapat dijelaskan bahwa sebagian besar atau 116 responden menyatakan partai politik bukan lagi menjadi acuan yang wajib diikuti oleh pemilih pemula. Selain faktor adanya jalur independent, banyaknya kasus korupsi yang menimpa para politisi yang berasal dari partai politik dijadikan pertimbangan oleh para siswa/i untuk tidak memilih kepala daerah yang berasal dari partai politik. Namun, ada juga para siswa/i yang memilih pasangan kandidat kepala daerahnya dari unsur partai politik hasil koalisi (gabungan).
Tabel 6

Dalam pilihan Pilkada, Anda mempertimbangkanlatar belakang prestasi yang telah dicapai oleh kandidat

\begin{tabular}{|l|l|l|}
\hline Pernyataan & $\mathbf{f}$ & $\mathbf{\%}$ \\
\hline Sangat Setuju & 84 & 31,3 \\
\hline Setuju & 122 & 45,5 \\
\hline Netral & 50 & 18.6 \\
\hline Tidak Setuju & 12 & 4,4 \\
\hline Jumlah & $\mathbf{2 6 8}$ & $\mathbf{1 0 0}$ \\
\hline
\end{tabular}

Sumber: Angket, 2015

Berdasarkan pada tabel diatas, menunjukkan bahwa jawaban terhadap item tersebut, sebanyak 84 responden atau 31,3 persen memberikan jawaban sangat setuju, sebanyak 122 responden atau 45,5 persen menyatakan setuju, sebanyak 50 responden memberikan jawaban netral atau 18,6 persen, dan sebanyak 12 responden memberikan jawaban tidak setuju atau 4,5 persen.

Prestasi yang dimiliki oleh calon pasangan kepala daerah di kabupaten Bandung menjadi suatu hal yang penting untuk dipertimbangkan. Dengan adanya prestasi secara individual maupun organisasi, maka setidaknya akan menularkan prinsip-prinsip untuk meraih prestasi tersebut dalam manajemen pemerintahannya. Adanya prestasi dapat memberikan peluang kerjasama yang lebih luas lagi bagi penyelanggaraan tata kelola pemerintahan yang baik melalui membuka networking dengan para investor dalam negeri maupun luar negeri. Pemilih yang mempertimbangkan pada aspek prestasi terhadap capaian kinerja partai atau kontestan termasuk pada kategori pemilih kritis. Pemilih kritis ini merupakan perpaduan antara tingginya orientasi pada kemampuan partai politik atau seorang konstestan dalam menuntaskan permasalahan yang dihadapinya selama mengemban menjadi politisi atau pejabat (Firmanzah, 2008:121).

Berdasarkan pada tabel di atas, menunjukkan bahwa jawaban terhadap item tersebut, sebanyak 14 responden atau 5,2 persen memberikan jawaban sangat setuju, sebanyak 65 responden atau 24,3 persen menyatakan setuju, sebanyak 61 responden memberikan jawaban netral atau 22,7 persen, sebanyak 99 responden memberikan jawaban tidak setuju atau 37 persen, dan sebanyak 29 responden memberikan jawaban sangat tidak setuju atau 10,8 persen. 
Tabel 7

Dalam pilihan Pilkada, Anda tidak mempertimbangkan latar belakang pendidikan yang telah dicapai oleh kandidat

\begin{tabular}{|l|l|l|}
\hline Pernyataan & f & \% \\
\hline Sangat Setuju & 14 & 5,2 \\
\hline Setuju & 65 & 24,3 \\
\hline Netral & 61 & 22,7 \\
\hline Tidak Setuju & 99 & 37 \\
\hline Sangat Tidak Setuju & 29 & 10,8 \\
\hline Jumlah & $\mathbf{2 6 8}$ & $\mathbf{1 0 0}$ \\
\hline
\end{tabular}

Sumber: Angket, 2015

Indeks pendidikan menjadi hal yang penting untuk dijadikan rujukan, sebab tingkat pendidikan dapat memberikan peluang-peluang ide gagasan yang baru dalam tata kelola manajemen pemerintahannya. Idealnya semakin tinggi pendidikan kandidat kepala daerah maka akan semakin segar tentang ideide pembangunan baik fisik maupun SDM yang berkualitas. Dikarenakan pemilih pemula yang dijadikan sasaran dalam sosialisasi kebanyakan ialah kaum pelajar, maka setidak preferensi mengenai pendidikan kandidat menjadi salah satu acuan dalam memilih pemimpin yang berpendidikan di masa yang akan datang. Sehingga para pelajar beharap dengan memiliki pemimpin yang berpendidikan maka setidaknya daerah yang dipimpinnya akan merasa bangga.

Data menunjukkan bahwa walaupun secara kasat mata (pragmatis) di masyarakat bahwa pemimpin yang berpendidikan maupun tidak berpendidikan sedikitnya dapat mempengaruhi dalam membuat suatu kebijakan pembangunan yang pro rakyat. Pendidikan dapat dijadikan nilai jual oleh partai atau konstestan yang ikut dalam peilihan kepala daerah. Sebab pendidikan merupakan suatu aktivitas mempengaruhi, mengubah, dan membentuk sikap dan perilaku berdasar nilai-nilai yang telah dianggap benar dan telah memberi manfaat bagi kehidupan manusia (Harun dan Sumarno, 2006:90).
Tabel 8

Dalam pilihan Pilkada, Anda mempertimbangkan latar belakang pengalaman kerja/organisasi yang telah dicapai oleh kandidat

\begin{tabular}{|l|l|l|}
\hline Pernyataan & $\mathbf{f}$ & \% \\
\hline Sangat Setuju & 78 & 29,1 \\
\hline Setuju & 134 & 50 \\
\hline Netral & 42 & 15,7 \\
\hline Tidak Setuju & 14 & 5,2 \\
\hline Jumlah & $\mathbf{2 6 8}$ & $\mathbf{1 0 0}$ \\
\hline
\end{tabular}

Sumber: Angket, 2015

Berdasarkan pada tabel di atas, menunjukkan bahwa jawaban terhadap item tersebut, sebanyak 78 responden atau 29,1 persen memberikan jawaban sangat setuju, sebanyak 134 responden atau 50 persen menyatakan setuju, sebanyak 42 responden memberikan jawaban netral atau 15,7 persen, dan sebanyak 14 responden memberikan jawaban tidak setuju atau 5,2 persen.

Pengalaman menjadikan seorang calon kandidat kepala daerah akan memberikan contoh suri tauladan dalam hal kepemimpinan. Apabila pemimpin yang telah berpengalaman dalam memimpin suatu organisasi setidaknya terbiasa dalam menghadapi permasalahan-permasalahan yang bersifat makro maupun mikro. Sehingga tidak salah apabila pengalaman menjadi salah satu ukuran bagi pemilih pemula untuk menentukan pimpinannya.

Corry (2009) memberikan pernyataan bahwa dalam perspektif komunikasi, upaya mewujudkan kesejahteraan masyarakat melalui pemilihan umum, barangkali bisa diwujudkan, ketika etika komunikasi bisa terpenuhi sebagaimana gagasan Karl Wallace Johannesen (1996) yakni pedoman etika yang berakar dalam nilai-nilai demokrasi, antara lain komunikator harus menumbuhkan kebiasaan besikap adil dalam memilih dan menampilkan fakta dan pendapat secara terbuka yang dicirikan melalui penyampaian riwayat keorganisasian yang telah dilakukan oleh kandidat sebagai pengalaman yang bisa dibuktikan apabila suatu saat terpilih menjadi pemimpin. Artinya seorang kandidat pemimpin daerah dituntut secara etis untuk memikirkan nasib dan kebersamaan dengan pihak lain dalam lingkungan tempat ia berada sebagai bukti kesungguhan bahwa ia seorang yang kompeten di bidangnya. 
Tabel 9

Dalam pilihan Pilkada, Anda tidak mempertimbangkan preferensi keluarga (rujukan dari ayah/ibu/saudara) untuk memilih kandidat

\begin{tabular}{|l|l|l|}
\hline Pernyataan & $\mathbf{f}$ & \% \\
\hline Sangat Setuju & 41 & 15,3 \\
\hline Setuju & 76 & 28,4 \\
\hline Netral & 108 & 40,3 \\
\hline Tidak Setuju & 37 & 13,8 \\
\hline Sangat Tidak Setuju & 6 & 2,2 \\
\hline Jumlah & $\mathbf{2 6 8}$ & $\mathbf{1 0 0}$ \\
\hline
\end{tabular}

Sumber: Angket, 2015

Berdasarkan pada tabel di atas, menunjukkan bahwa jawaban terhadap item tersebut, sebanyak 41 responden atau 15,3 persen memberikan jawaban sangat setuju, sebanyak 76 responden atau 28,4 persen menyatakan setuju, sebanyak 108 responden memberikan jawaban netral atau 40,3 persen, sebanyak 37 responden memberikan jawaban tidak setuju atau 13,8 persen, dan sebanyak 6 responden memberikan jawaban sangat tidak setuju atau 2,2 persen.

Keluarga merupakan unsur utama dalam pendidikan informal. Sebab di keluarga lah kita dididik dan diberi pelajaran maupun pengatahuan tentang bagaimana cara hidup bermasayarakat yang baik. Maka, tidak salah apabila keluarga sering dijadikan rujukan dalam memilih calon pemimpinnya. Karena dalam keluarga juga sering ada yang menerapkan konsep demokrasi, otoriter, maupun liberal dalam menentukan pemimpin-pemimpin masa depan.

Fitzpatrick, dkk. menyatakan bahwa komunikasi keluarga tidaklah bersifat acak tetapi sangat terpola berdasarkan skema-skema tertentu yang menentukan bagaimana anggota keluarga berkomunikasi antara satu dengan lainnya. Skema-skema ini terdiri atas pengetahuan mengenai seberapa intim suatu keluarga, derajat indidualitas dalam keluarga, dan faktor eksternal keluarga (teman, jarak geografis, pekerjaan). Dalam kenyataan di lapangan para pemilih pemula jarang melakukan komunikasi dengan keluarganya tentang politik, sehingga skema pengetahuan para pemilih pemula menjadi variatif (Morissan, 2002:161-162).
Tabel 10

Dalam pilihan Pilkada, Anda mempertimbangkan preferensi media massa (rujukan dari radio, tv, koran, majalah) untuk memilih kandidat

\begin{tabular}{|l|l|l|}
\hline Pernyataan & $\mathbf{f}$ & \% \\
\hline Sangat Setuju & 31 & 11,6 \\
\hline Setuju & 113 & 42,2 \\
\hline Netral & 88 & 32,8 \\
\hline Tidak Setuju & 28 & 10,4 \\
\hline Sangat Tidak Setuju & 8 & 3 \\
\hline Jumlah & $\mathbf{2 6 8}$ & $\mathbf{1 0 0}$ \\
\hline
\end{tabular}

Sumber: Angket, 2015

Berdasarkan pada tabel di atas, menunjukkan bahwa jawaban terhadap item tersebut, sebanyak 31 responden atau 11,6 persen memberikan jawaban sangat setuju, sebanyak 113 responden atau 42,2 persen menyatakan setuju, sebanyak 88 responden memberikan jawaban netral atau 32,8 persen sebanyak 28 responden memberikan jawaban tidak setuju atau 10,4 persen, dan sebanyak 8 responden memberikan jawaban sangat tidak setuju atau 3 persen. Data diatas, menyimpulkan bahwa responden setuju ketika memilih seorang kandidat nanti dalam pilkada 9 Desember 2015 nanti akan mempertimbangkan preferensi informasi yang diberitakan oleh media massa tentang kandidat tersebut.

Acara-acara maupun program dalam media massa pada umumnya dapat mempengaruhi sikap, pandangan, persepsi, dan perasaan khalayak sehingga membuat mereka kadang-kadang terhipnotis dan terhanyut dalam acara tersebut. Bahasa yang digunakan dalam media massa turut memberikan pengaruh pada pemakaian dan pola pikir khalayak. Menurut teori Gramci, media massa merupakan alat yang digunakan elit berkuasa untuk melestarikan kekuasaan, kekayaan, dan status mereka sendiri (Boggs, 1976:39). Media massa secara unik memperkenalkan unsur-unsur ke dalam kesadaran individual yang jika tidak demikian, tak akan muncul, tetapi tak akan ditolak oleh kesadaran karena unusr-unsur itu dirasakan bersama dalam komunitas budaya itu (Nordenstereng, 1977:276).

Dampak media dalam analisis akademis terdapat pada kajian komunikasi yang salaing berlawanan, yaitu pandangan yang menyatakan bahwa terdapat media yang mempunyai pengaruh yang kuat dengan pandangan yang menekankan bahwa media mempunyai pengaruh yang sedikit saja terhadap 
khalayak (Teori Uses and Gratification). Kemudian studi yang dilakukan oleh Paul F. Lazarfeld, Bernard Barelson, dan Hazel (1944) menyatakan bahwa hubungan-hubungan personal-lah yang lebih menentukan pilihan-pilihan mereka terhadap kandidat dibandingkan dengan pengaruh langsung media massa (McQuail dan Windahl, 1981). Berdasarkan studi ini, Katz dan Lazarfeld menyusun suatu model komunikasi dua tahap dimana pengaruh media massa akan berlansung melalui opinion leader dan selanjutnya diteruskan melalui kontak personal.

Pemilih pemula yang sebagian besar remaja, yang sedang mencari identitas diri dalam proses transisi dan anak-anak menuju dewasa, merupakan kalangan yang mudah terpengaruh oleh berbagai budaya asing yang hadir melalui media massa. Padahal, keterlibatan media massa dengan kegiatan politik, tidak semata-mata mencerminkan perhatian media terhadap politik, melainkan menyiratkan pula adanya keterikatan atas dasar suatu kepentingan antara sebuah media politik ataupun idiologis (Hamad, 2004:75). Hal ini terungkap bagaimana isi pemberitaan suatu partai politik di media massa diberitakan secara positif guna menarik simpati dari konstituennya atau masyarakat yang lebih luas.

Tabel 11

Dalam pilihan Pilkada, Anda tidak mempertimbangkan preferensi media online (rujukan dari twitter, facebook, Path, line, whatsap, youtube, dII) untuk memilih kandidat

\begin{tabular}{|l|l|l|}
\hline Pernyataan & $\mathbf{f}$ & \% \\
\hline Sangat Setuju & 20 & 7,5 \\
\hline Setuju & 57 & 21,3 \\
\hline Netral & 111 & 41,4 \\
\hline Tidak Setuju & 64 & 23,9 \\
\hline Sangat Tidak Setuju & 16 & 5,9 \\
\hline Jumlah & $\mathbf{2 6 8}$ & $\mathbf{1 0 0}$ \\
\hline
\end{tabular}

Sumber: Angket, 2015

Berdasarkan pada tabel di atas, menunjukkan bahwa jawaban terhadap item tersebut, sebanyak 20 responden atau 7,5 persen memberikan jawaban sangat setuju, sebanyak 57 responden atau 21,3 persen menyatakan setuju, sebanyak 111 responden memberikan jawaban netral atau 41,4 persen, sebanyak 64 responden memberikan jawaban tidak setuju atau 23,9 persen, dan sebanyak 16 responden memberikan jawaban sangat tidak setuju atau 5,9 persen.

Posisi media, baik media konvensional maupun mediabaru(online) menjadisignifikan dalamberagam konteks, tak terkecuali konsteks politik di Indonesia, sebab dapat dijadikan sarana penyampaian pesan atau isu politik yang dikaitkan dengan permasalahan publik. Komunikasi politik melalui internet yang memanfaatkan media sosial memberikan immediacy, aksesibilitas, dan keberlanjutan pada ekspresi moral, emosi dan psikologis dengan standar dan konvensi interakasi komunikasi melalui internet seperti iklan, mentions, hashtags, retweet, likes, comments, maupun love. Sehingga pengguna web tidak lagi merupakan khalayak pasif, tetapi partisipan aktif yang selalu mengontrol isi informasi secara cepat dan berkelanjutan. Upaya mengontrol isi informasi ini menurut Abrar dalam Iriantara (2008:119) merupakan bagian dari konsekuensi sosial, yaitu terjadinya perubahan hubungan sosial dan transformasi sosial melalui computer mediated communications (CMC) membuat orang tidak berhubungan secara tatap muka melainkan "bertatap muka" secara maya melalui layar komputer (android) yang membentuk suatu jaringan komunikasi melalui perangkat internet.

Internet adalah media komunikasi baru yang sangat cepat perkembangannya secara software maupun hardware guna menunjang kehidupan umat manusia. Dalam konteks politik, keberadaan perangkat program media sosial menjadi mempunyai peranan dan fungsi yang paling penting dalam mendongkrak jumlah suara secara kuantitatif melalui media internet ini yang tercermin dalam jumlah followers (pengikut) yang mengomentarinya. Menurut Kriyantono (2008:240) jaringan internet yang dilakukan secara mengglobal dapat menciptakan suatu keadaan yang sarat dengan informasi (Information superhighway) yang amat luas dan seakan-akan tidak berujung. Hal ini senada dengan pernyataan McLuhan dengan konsepnya The Global Village, yang dimana dunia dikesankan sangat kecil di mana kita bisa saling mengenal dan mengetahui berbagai peristiwa dan orang dalam suatu saat yang serba singkat, meski dibatasi oleh jarak yang jauh. 
Tabel 12

Dalam pilihan Pilkada, Anda mempertimbangkan preferensi media tradisional (rujukan dari spanduk, poster, leaflet) untuk memilih kandidat

\begin{tabular}{|l|l|l|}
\hline Pernyataan & f & \% \\
\hline Sangat Setuju & 26 & 9,7 \\
\hline Setuju & 119 & 44,4 \\
\hline Netral & 93 & 34,7 \\
\hline Tidak Setuju & 27 & 10,1 \\
\hline Sangat Tidak Setuju & 3 & 1,1 \\
\hline Jumlah & $\mathbf{2 6 8}$ & $\mathbf{1 0 0}$ \\
\hline
\end{tabular}

Sumber: Angket, 2015

Berdasarkan pada tabel di atas, menunjukkan bahwa jawaban terhadap item tersebut, sebanyak 26 responden atau 9,7 persen memberikan jawaban sangat setuju, sebanyak 119 responden atau 44,4 persen menyatakan setuju, sebanyak 93 responden memberikan jawaban netral atau 34,7 persen, sebanyak 27 responden memberikan jawaban tidak setuju atau 10,1 persen, dan sebanyak 3 responden memberikan jawaban sangat tidak setuju atau 1,1 persen.

Komunikator politik, apakah itu politikus, profesional ataupun aktivis menggunakan penyampaian pesan secara persuasif, baik untuk saling mempengaruhi maupun untuk mempengaruhi anggota khalayak yang kurang terlibat di dalam politik. Media atau alat untuk mengirimkan pesan itu dinamakan "Saluran atau Media yang berfungsi siapa mengatakan apa kepada siapa". Saluran adalah ciptaan makhluk pemakai lambang untuk melancarkan saling tukar pesan (Kenneth Burke dalam Nimmo, 2000:166-167).

Media-media komunikasi yang berupa spanduk, poster dan leaflet sering dijadikan sarana utama dalam mensosialisasikan seorang kandidat calon pemimpin kepala daerah. Media ini sering digunakan dikarenakan ongkos biayanya relatif lebih murah ketimbang beriklan di media massa. Selain itu, responden menganggap pesan-pesan yang ada di media tradisional mudah dilihat sepanjang waktu karena terdapat di daerah-daerah strategis seperti kantor desa, jalan-jalan protokol, maupun di kantor-kantor pemerintahan lainnya. Mengadopsi pernyataan Jonatan dalam Suryadi (2011:108) yang menunjukkan bahwa dari sekian jenis media luar ruang sebagaimana tersebut diatas memiliki landmark marketing karena diharapkan secara jangka panjang dapat mengkristalisasi icon suatu merek di benak khalayak tentang pesan-pesan disampaikan melalui media luar ruang seperti spanduk, baliho, pamflet, maupun poster.

Tabel 13

Dalam pilihan Pilkada, Anda tidak mempertimbangkan preferensi asal kandidat dari kaum selebritas (artis, budayawan, seniman, dsb)untuk memilih kandidat

\begin{tabular}{|l|l|l|}
\hline Pernyataan & f & \% \\
\hline Sangat Setuju & 30 & 11,2 \\
\hline Setuju & 89 & 33,2 \\
\hline Netral & 105 & 39,2 \\
\hline Tidak Setuju & 41 & 15,3 \\
\hline Sangat Tidak Setuju & 3 & 1,1 \\
\hline Jumlah & $\mathbf{2 6 8}$ & $\mathbf{1 0 0}$ \\
\hline
\end{tabular}

Sumber: Angket, 2015

Berdasarkan pada tabel di atas, menunjukkan bahwa jawaban terhadap item tersebut, sebanyak 30 responden atau 11,2 persen memberikan jawaban sangat setuju, sebanyak 89 responden atau 33,2 persen menyatakan setuju, sebanyak 105 responden memberikan jawaban netral atau 39,2 persen, sebanyak 41 responden memberikan jawaban tidak setuju atau 15,3 persen dan sebanyak 3 responden memberikan jawaban sangat tidak setuju atau 1,1 persen.

Sosok selebriti menjadi kajian yang menarik, terutama jika berkait dengan suara rakyat atau mayoritas masyarakat yang akan memilih. Dan biasanya sosok selebritis dijadikan sebagai endorser dalam kegiatan kampanye pemilu pada pilkada. Endorser menurut Suryadi (2011) adalah icon atau sosok yang dipakai dalam kegiatan komunikasi yang bertujuan untuk mendukung efektifitas penyampaian suatu pesan. Sehingga icon status pribadi ataupun kelompok yang masyhur menjadi komoditas yang dapat "dijual" pada masyarakat yang berpotensi mampu mengarahkan opini publik ataupun preferensi pasangan calon, meski terkait potensi tersebut juga perlu mendapat kajian tersendiri.

Hal yang pasti adalah secara faktual, fenomena selebriti dalam konteks politik menjadi makin masif dengan pesan politik yang disampaikan, baik melalui wawancara yang dilakukan di media massa ataupun muncul pada akun pribadi online social media yang dimilikinya. Meski demikian, selebriti memiliki fungsi sosial dan diposisikan sebagai representasi, wacana, dan industri serta formasi kultural, sehingga selebriti menyediakan tubuh teks yang kaya akan semiotik dan wacana komunikasi. Sehingga 
realitas menunjukkan bahwa sosok kandidat dengan mengandalkan kepopuleran sebagai kaum selebritis belum menunjukkan hasil yang sangat mempengaruhi para pemilih pemula dalam kegiatan Pilkada di masa mendatang.

\section{KESIMPULAN}

Kesimpulan penelitian ini adalah: (1) pilihan dan perilaku politik pemilih pemula (pelajar SMAN) di Kabupaten Bandung pada Pilkada menunjukkan sebagian besar siswa menentukan pilihannya berdasarkan preferensi media massa dan hasil komunikasi antarpesona yang dilakukan oleh tim sukses kampanye pasangan Cabup dan Cawabup sebagai bentuk tanggungjawab menjadi warga negara yang baik; dan (2) perilaku politik pemilih pemula (pelajar SMAN) dalam menentukan pilihan pasangan Cabup-Cawabup Kabupaten Bandung pada Pilkada dapat dikategorikan sebagai pemilih yang memilih calon pemimpinnya berdasarkan pertimbangan rasional/kritis (merujuk pada hasil kinerja), psikologis/pragmatis/skeptis (unsur pengaruh terpaan informasi), dan sosiologis/ tradisional (unsur pengaruh persuasi ikatan SARA).

\section{DAFTAR PUSTAKA}

Boggs, C. (1976). Gramcis Marxism. London: Pluto Press.

Badan Pusat Statistik (BPS) Kabupaten Bandung tahun 2014.

Darmastuti, Rini, dkk. (2015). Budaya Komunikasi Politik dalam Konsep Kearifan Lokal Masyarakat Solo. Prosiding: Konferensi Nasional Komunikasi Politik. Malang: Prodi Ilmu Komunikasi Fakultas Ilmu Sosial dan Politik Universitas Brawijaya.

Firmanzah. (2008). Marketing Politik: Antara Pemahaman dan Realitas. Jakarta: Yayasan Obor Indonesia.

Geertz, Clifford.(1981). Abangan, Santri, Priyayi dalam Masyarakat Jawa. Terjemahan: Aswab Mahasin. Bandung: Dunia Pustaka Jaya.

Hamad, Ibnu. (2004). Konstruksi Realitas Politik dalam Media Massa (Studi Pesan Politik dalam Media Cetak Pada Masa Pemilu 1999) Makara, Sosial Humaniora, Vol.8, No.1, April 2004.

Harrop, Martin dan Miller, William L.,.(1987). Election and Voters: A Comparative Introduction. London: Macmillan Education.

Harun, Rochajat dan AP., Sumarno.(2006). Komunikasi Politik Sebagai Suatu Pengantar. Bandung: CV.
Mandar Maju.

Iriantara, Yosal. (2008). Media Relations: Konsep, Pendekatan, dan Praktik. Bandung: PT. Simbiosa Rekatama Media.

Johannesen, Richard L. (1996). Ethics in Human Communication. Prospect Heigths, III. Waveland Press.

Katz, E.(1980). On Conceptualizing Media Effects dalam T. McComrmack (Ed.), Studies in Communications (pp.199-141).Greenwich, CT: JAI Press.

Kriyantono, Rachmat. (2008). Public Relations Writing. Jakarta: Kencana Prenada Media Group.

McAllister, Ian. (1992). Political Behaviour: Citizens, Parties and Elites in Australia. Australia: Longman Cheshire.

Mcquail, Dennis dan Sven Windahl. (1981). Communication Model: For the Study of Mass Communication. London and New York: Longman.

Morissan. (2002). Psikologi Komunikasi. Bogor: Ghalia Indonesia.

Nastsir, Muhammad. (1995). Metode Penelitian. Jakarta: Ghalia Indonesia

Nimmo, Dan. (2000). Komunikasi Politik: Komunikator, Pesan dan Media. Bandung: PT.Remaja Rosdakarya.

(2001). Komunikasi Politik: Khalayak dan Efek. Bandung: PT. Remaja Rosdakarya.

Norhabiba, Fitri. (2015). Konsumsi Media Mengenai Polling Politik dan Praktik Demokrasi di Indonesia. Prosiding: Konferensi Nasional Komunikasi Politik. Malang: Prodi Ilmu Komunikasi Fakultas Ilmu Sosial dan Politik Universitas Brawijaya.

Nurasi, Adman. (2004). Political Marketing: Strategi Memenangkan Pemilu. Jakarta: Gramedia Pustaka Utama.

S. Salossa, Daniel. (2005). Pilkada Langsung. Yogyakarta: Media Presindo.

Sahdan, Gregious. (2004). Pembangunan Partisipasi Politik Dalam Pemilu. Jakarta: CSIS.

Singarimbun, Masri. (1989). Metode Penelitian Survai. (Ed.Revisi). Jakarta: LP3ES.

Sudijono. (1995). Perilaku Politik. Semarang: Pustaka Utama.

Suryadi, Didih. (2011). Promosi Efektif: Menggugah Minat \& Loyalitas Pelanggan. Yogyakarta: Oryza.

Usman, Husaini. (2009). Metodologi Penelitian Sosial, edisi kedua. Jakarta: Bumi Aksara.

W. Corry Andy. (2009). Etika Komunikasi dalam Penyampaian Aspirasi. Jurnal Komunikasi, 1 (1), 14-18. 